International Journal of Agriculture, Environment and Bioresearch

Vol. 5, No. 05; 2020

ISSN: $2456-8643$

\title{
PHENOLOGICAL BEHAVIOUR AND MEDICINAL USES OF EUPHORBIA HIRTA LINN. IN DIARA LAND OF HAJIPUR, BIHAR
}

\author{
Shashi Bhushan Sinha \\ Department of Botany ,R.B. College, Dalsingsarai, Samastipur ,Lalit Narayan Mithila University, Darbhanga, India
}

https://doi.org/10.35410/IJAEB.2020.5569

\begin{abstract}
The present investigation showed that the extracts of E. hirta Linn. displayed antibacterial activities. The powdered plant material of Euphorbia hirta was extracted in three solvents ethanol, benzene and water using the Soxhlet extraction apparatus 241 (PSAWINDIA).: The percentage yields of the extracts were 58 (water), 32 (ethanol), and 15 (benzene). Phytochemical screening of the crude extracts revealed the presence of saponins, flavonoids, cardiac glycosides, cyanogenic glycosides, anthraquinones, and alkaloids. The presence of these constituents was linked to the antibacterial activity of the plant, using the agar well-diffusion method. The results suggested that the use of the extracts of E. hirtaLinn. as an oral medication, both on short -term and long-term was not safe, due to the presence of some toxic constituents.
\end{abstract}

Keywords: Euphorbia hirtaLinn.,Ethanol extract, Benzene extract, phytochemical, water extract.

\section{INTRODUCTION}

Euphorbia hirta belongs to the family Euphorbiaceae. It is a small annual herb common to tropical countries [1]. The plant has been used for female disorders but is now more important in treating respiratory ailments, especially cough, coryza, bronchitis and asthma. In India it is used to treat worm infestations in children and for dysentery, gonorrhea, jaundice, pimples, digestive problems and tumors [2]. The plant is also widely used in Angola against diarrhea and dysentery, especially amoebic dysentery. In Nigeria extracts or exudates of the plant are used as ear drops and in the treatment of boils, sore and promoting wound healing [3,4]. The alcoholic extract of Euphorbia hirta leaves is highly effective against gram positive bacteria and moderately effective against gram negative bacteria. This work was carried out to determine the in-vitro activities of Euphorbia hirta extracts on some clinical isolates.

\section{MATERIALS AND METHODS}

\section{Collection of Plant Material}

The fresh plant of E. hirtaLinn.was collected from Diara land of Hajipur, Vaishali district in Bihar, India .

\section{Preparation of Plant Material}


The fresh plant was rinsed with tap water and air-dried under shade for a week, and then reduced to coarse powder using a pestle and mortar. Subsequently, it was ground into fine powder using the Kenwood electric blender (Kenwood Limited, Havant, United Kingdom). The powder was then stored in an airtight bottle for further use.

\section{Preparation of the Extracts}

Two hundred grams of the powdered sample (whole plant) was soaked in $100 \mathrm{ml}$ of solvent in a Soxhlet extractor 241(PSAWINDIA) and left to stand for 24 hours, to extract. The filtrate was then evaporated to dryness using a rotary evaporator attached to a vacuum pump (Model type 349/2, Corning Limited). The percentage yield of the crude extract was determined for each solvent; for water it was $59 \%$, for methanol $33 \%$, and for benzene $16 \%$. The percentage extract yield was estimated as dry weight/dry material weight $\times 100$ [5]. For the preparation of the dilutions of crude extracts for antibacterial assay, the extracts was reconstituted by dissolving in the respective extracting solvents and further diluted with distilled water to obtain 400, 200, 100, $50,25,12.5,6.25,3.085$, and $1.03 \mathrm{mg} / \mathrm{ml}$. The reconstituted extracts were maintained at a temperature between 2 and $8^{\circ} \mathrm{C}$.

\section{Phytochemical Screening of the Plant Material}

Phytochemical screening was carried out on the powdered plant material for the presence of bioactive components, such as, tannins, phenols, alkaloids, cardiac glycosides, anthraquinones, cyanogenic glycosides, saponins, and flavonoids [6].

\section{RESULTS AND DISCUSSIONS}

Percentage yield of the powdered plant Euphorbia hirta Linn. crude extracts, obtained using various solvents are shown Table 1 . Out of the $200 \mathrm{~g}$ of powdered plant material, the percentage yield obtained for water was $58 \%$, for ethanol $32 \%$, and for benzene $15 \%$. Phytochemical screening of the crude extracts of E. hirta Linn.revealed the presence of some bioactive components as shown in Table 2. It contained tannins, terpenes, cardiac glycosides, anthraquinones, saponins, cyanogenic glycosides, flavonoids, and alkaloids.

The percentage yield obtained for water was 58\%, for ethanol $32 \%$, and for benzene $15 \%$ ( Table 1 ). This yield was not far lower than that obtained by Doughari et al. [7] for Sennaangustifolia as they reported a yield of $52 \%$ for water extract, $50 \%$ for benzene extract, and $28 \%$ for dichloromethane, and also that of Owolabi et al . [8] who reported a yield of $10.74 \%$ for water extract and $3.78 \%$ for their ethanol extracts. Ogbolie et al. [9] also reported a yield of 9.1\% for water extracts of E. hirta Linn. . Factors like the age of the plant and the polarity of the solvent used affected the yield. Thus, in this study, water seemed to be the best solvent for this plant material, thus supporting the use of water as a solvent of choice in traditional practice.

The results obtained in this study support the methods used by the traditional healers. It is evident from the results that water extract has some significantly low antibacterial activity, suggesting that the active principles are more soluble in water, and that water is the appropriate solvent for the extraction of the bioactive constituents present in E. hirta Linn.[10, 11]. 
Vol. 5, No. 05; 2020

ISSN: $2456-8643$

\section{CONCLUSIONS}

The present investigation showed that the extracts of E. hirta Linn. displayed antibacterial activities. However, long term use of the extract was slightly toxic in experimental animals, even though it was potent on the bacteria, which points to its toxicity in the vital organs such as liver, lungs, kidneys, spleen, and heart. It is therefore suggested that detoxification of the constituents responsible for its toxicity be researched upon for effective ethno- medicinal prescriptions of the plant.

\section{REFERENCES}

1. Sofowora, E. A. (1982). Medicinal plants and traditional medicine in Africa. John Wiley and sons LTD, Chichester. Pp 198.

2. Kirtikar, K. R. and Basu, B. D.(1991). Indian Medicinal Plants, Periodical Experts Books Agency, 2nd edition, vol. 3, New Delhi.

3. Igoli, J. O., Ogaji, T. A., Tor-Anyiin and Igoli, N. P. (2005). Traditional Medicine Practice Amongst the Igede People of Nigeria. Afr. J. Trad. CAM. 2(2); $134-152$.

4. Anon. (2005). The use of Euphorbia hirta in the treatment of sores, boils and wounds.

5. Parekh J ,Chanda S . (2007). In vitro antimicrobial activity of TrapanatansL.fruit rind extracted in different solvents .Afr. J. Biotechnology. 6 ( 16 ): 1905 - 1909.

6. TreaseGE, Evans WC . (1996). Pharmacognosy . 15 th Edition, Elsevier publishers. 56 109 .

7. AdesokanAA, Akanji MA, Yakubu MT. (2007). Antibacterial potentials of aqueousextract of Enantiachloranthastem bark .Afr. J. Biotechnology. 6( 22 ): 2502 2505 .

8. OyelekeSB ,Dauda BEN, Boye OA . (2008). Antibacterial activity of Ficuscapensis.Afr. J. Biotechnology. 7 ( 10 ): $1414-1417$.

9. OgbolieJN, Ogeke CC, Okoli IC, Anyanwu BN. (2007). Antibacterial activitiesand toxicological potentials of crude ethanol extracts of Euphorbia hirta.Afr. J. Biotechnology. 6 ( 13 ): $1544-1548$.

10. FalodunA, Okunrobe LO, Uzoamaka N. (2006). Phytochemical screening andantiinflammatory evaluation of methanol and aqueous extracts of Euphorbia heterophyllaLinn9Euphorbiaceae).Afr. J. Biotechnol. 5 ( 6 ): $529-531$.

11. MahoomadH ,Amey M.(200). Molecular basis of bacterial outer membranepermeability Microbial. Rev. $1: 1-32$ 
Table 1: Percentage yields of extracts of $E$. hirta Linn.

\begin{tabular}{|l|l|}
\hline Extraction Solvent & Yields (\%) \\
\hline Water & 58.0 \\
\hline Ethanol & 32.0 \\
\hline Benzene & 15.0 \\
\hline
\end{tabular}

Table 2: Phytochemical screening and chromatographic resolution of crude extracts

\begin{tabular}{|l|l|l|l|}
\hline Class of compounds & \multicolumn{2}{|l|}{ RF values of spots } & \multicolumn{2}{l|}{} \\
\cline { 2 - 4 } & Aqueous & Ethanol & Benzene \\
\hline Alkaloids & 0.51 & 0.79 & - \\
\hline Flavonoids. & 0.72 & 0.82 & 0.81 \\
\hline Saponins & & & \\
\hline Tannins & 0.79 & 0.63 & 0.76 \\
\hline Anthraquinones & 0.83 & 0.88 & 0.84 \\
\hline Cyanogenicgly & 0.89 & 0.61 & - \\
\hline Terpenes & 0.70 & 0.65 & 0.63 \\
\hline Cardiac gly & 0.88 & 0.62 & 0.66 \\
\hline
\end{tabular}

